\title{
Problem-based case study to enhance critical thinking in student nurses
}

\author{
NM Mogale, M.Cur student, Department of Nursing, Rand Afrikaans University \\ AC Botes, D.Cur, Professor, Department of Nursing, Rand Afrikaans University
}

\section{Abstract}

The use of traditional teaching methods, for example the lecture method, does not stimulate critical thinking in student nurses. This problem can be solved by the utilisation of problem-based case study in the classroom/clinical setting. The purpose of this study is to describe guidelines for the implementation of problem-based case study in a clinical setting among first year, comprehensive course students at the Northern Province College of Nursing: Sovenga campus.

The research design of this study was qualitative, explorative, descriptive and contextual and was conducted in the following phases:

Phase 1: The development and implementation of a program for problem-based case study in the clinical setting; Phase II: The experiences of student nurses who were exposed to problem-based case study in the clinical setting; Phase III: The perceptions of tutors regarding the implementation of problem-based case study in the clinical setting (focus group), and;

ase IV: Guidelines for the implementation of problem-based case study.

The data from Phases I, II and III were used to formulate guidelines for the implementation of problem-based case study.

The sample group consisted of all 69 first year student nurses at the Northern Province College of Nursing: Sovenga campus and ten tutors teaching clinical courses at the same campus.

The Tesch (1990) approach is used for data analysis.

Nine guidelines for the implementation of a problem-based case study approach were formulated and recommendations for development of an instrument to measure critical thinking in nursing were recommended.

\section{Opsomming}

Die gebruik van tradisionele onderwysmetodes, soos byvoorbeeld die lesingmetode, stimuleer nie kritiese denke by studentverpleegsters nie. Hierdie probleem kan die hoof gebied word deur gebruik te maak van probleemgebaseerde gevallestudie in die klaskamer/kliniese omgewing. Die doel van hierdie studie is om riglyne te omskryf vir die in werking stelling van probleemgebaseerde gevallestudie in die kliniese omgewing onder eerstejaar, omvattende kursus studente aan die Northern Province College of Nursing: Sovengakampus.

Die navorsingsontwerp van hierdie studie is kwalitatief, verkennend, beskrywend en kontekstueel van aard. En is in vier fases uitgevoer, naamlik:

Fase 1: Die ontwikkeling en implementering van ' $n$ program vir probleemgebaseerde gevallestudie in die kliniese omgewing;

Fase II: Die ervarings van studentverpleegsters wat blootgestel is aan probleemgebaseerde gevallestudie in die kliniese omgewing;

Fase III: Die persepsies van studieleiers met betrekking tot die implementering van probleemgebaseerde gevallestudie in die kliniese omgewing (fokusgroup), en Fase IV: Riglyne vir die in werking stelling van probleemgebaseerde gevallestudie.

Die data vir die formulering van riglyne vir die operasionalisering van probleemgebaseerde gevallestudie is verkry uit Fases I, II en III.

Die Tesch (1990) benadering word gebruik met die analisering van data.

Nege riglyne vir die operasionalisering van probleemgebaseerde gevallestudie is beskryf en aanbevelings, vir die ontwikkeling van " $n$ instrument om kritiese denke te meet, is aanbeveel.

\section{Introduction and problem statement}

The use of traditional teaching methods at Northern Province College of Nursing: Sovenga campus does not enhance critical thinking in student nurses. The complexity of nursing practice demands that student nurses make competent judgements on the basis of reasoning that represents critical thinking. Brown \& Sorrel (1993:16) state that research in education indicates that critical thinking does not just happen for students. Beyer (1987:18) proposed that educators need to teach critical think- ing, by directly engaging students in substantive learning activities that require the kind of thinking we want them to develop. The possible solution to this problem, related to the development and teaching of critical thinking, may be the implementation of problem-based case study as a teaching strategy.

Problem-based case study is defined as an instructional method characterised by the use of patient problems as a context for the student to learn problem-solving skills and acquire knowledge about basic and clinical science (Ablanese \& Mitchell, 1993:52-81). This radical change in teaching strategy is also advocated by the Commission of Higher Education, which recommends that the curricula should shift from a content teach- 
ing centred curricula to a learning and outcomes based curricula. These outcomes cannot be reached by traditional teaching methods. The South African Nursing Council (1992:3) explicitly indicates in its philosophy that the development of critical thinking in nursing students is essential. This development of thought is necessary as we must function as independent nursing practitioner and apply the scientific methods. The use of traditional teaching methods, such as the lecture method does not stimulate critical thinking in student nurses. This is further compounded by the fact that nurse educators have inherited a population of students from disadvantaged secondary schools, who do not have the level of cognitive thinking that is necessary for effective problem-solving and critical thinking (Klaasens, 1988:15).

The nursing college has in great need of a change in teaching strategies to enhance critical thinking. No program or teaching strategy to enhance critical thinking existed in the nursing college. Because of the absence of an appropriate, cultural sensitive instrument to measure critical thinking the researcher decided on an exploratory, descriptive strategy to develop, implement and assess the problem-based case study as teaching strategy in clinical practice.

\section{Purpose and objectives of the research}

The purpose of this study was to describe guidelines for the operationalisation of problem-based case study in the clinical setting for first year comprehensive course students at the Northern Province College of Nursing: Sovenga campus. The specific research objectives were:

- To develop and implement a program of problembased case study to enhance critical thinking in first year comprehensive course students at the Northern Province College of Nursing: Sovenga campus.

- To explore and describe the experiences of the first year comprehensive course students, who were involved in problem-based case study as a learning strategy at the Northern Province College of Nursing: Sovenga Campus.

- To explore and describe the perception of tutors regarding implementation of the problem-based case study in the clinical setting at Northern Province College of Nursing: Sovenga campus.

\section{Research design and methods}

The research design of this study was qualitative, explorative, descriptive and contextual (Polit and Hungler, 1995:640-651). The research was conducted in four phases.

\section{Phase 1: Development and implementation of a program for problem-based case study.}

The program was developed from existing knowledge frameworks, using patients with elimination needs as an example. The program was implemented at Sovenga campus using three clinical domains namely Pietersburg, Mankweng and Doctor Machupe Mphahlele. Forty-six (46) participated in the program.

\section{Phase II: Experience of student nurses who were exposed to problem-based case study}

The objective of this phase was to explore and describe the experiences of student nurses at Northern Province College of Nursing: Sovenga campus, after exposure to problem-based case study in the clinical setting. This was done in order to identify principles that will be used for the implementation of the problem-based case study.

\section{Population and Sampling}

From the total population of 69 students $(\mathrm{N}=69)$, registered in January 1999 for the program leading to registration as a nurse (General, Psychiatric and Community) and midwifery at Northern Province College of Nursing, 46 students $(n=46)$ from Sovenga campus were included using a non-probability purposive sampling (Burn and Grove, 1993: 246).

\section{Data collection}

The method used to collect the data from the students was naive sketches (Ilson, Crystal, Well, Long and Corney 1987:1026). The students were asked to describe their experiences after exposure to the problem-based case study approach.

\section{Data analysis}

Data was analysed by open coding, based on the Tesch-approach (1990) (in Creswell, 1994:154-155). Sketches were independently analysed by the researcher and an independent coder.

\section{Phase III: Focus group interview with tutors teaching clinical courses.}

Focus group interviews were conducted with tutors teaching clinical courses at Sovenga campus in order to elicit their views regarding implementation of problem-based case study in the clinical setting.

\section{Population and Sampling}

Purposive sampling was used (Burns \& Grove, 1993:246 and Polit \& Hungler, (1997:229) based on the assumption that the researcher's knowledge about the population can be used to consciously select the participants. In this instance the researcher wanted a sample of tutors teaching clinical courses, namely general nursing, midwifery, psychiatric and community nursing. The recommended size of the focus group ranges from six to twelve participants (Krueger,1994: 78). In this study ten tutors participated in the focus group.

\section{Data Collection}

Data was collected by means of focus group interviews (Polit and Hungler, 1997:457). Phases 1 and 2 were explained to the 
tutors. The following open-ended question was asked: "What are your views about the implementation of problem-based case study at our college?" The interview was tape-recorded. A verbatim transcription of the discussion was made in the interest of trustworthiness.

\section{Data analysis}

Data analysis was done according to Tesch (1990) (in Cresswell, 1994: 154-155).

\section{Phase IV: Guidelines for the implementation of problem-based case study}

The data from phase I, II, III were used to formulate phase IV, which are the guidelines for the implementation of problembased case study.

\section{Trustworthiness}

The researcher used Lincoln and Guba's model (1985), which identifies criteria and strategies for establishing trustworthiness. The following measures were employed:

- Method triangulation. Focus groups, literature review, naïve sketches and exposure to problem-based case study achieved the use of multiple methods to address the research problem.

- $\quad$ Peer group debriefing. The researcher and a co-coder analysed the content of the naïve sketches transcription of the focus group.

- The focus group interview was tape-recorded and transcribed and field notes were taken during the interview.

- A dense description of the research methods is given.

\section{Ethical considerations}

The researcher complied with the ethical guidelines for research as described by DENOSA (1998).

\section{Conceptual framework and literature review}

A conceptual framework for this study is reflected in figure 1. This conceptual framework is used as a theoretical base for a programme of problem-based case study. This conceptual framework is divided into three components, namely

v Context: Situational Analysis.

$\mathrm{v}$ Descriptions and definitions of key concepts.

v Curriculum process.

Figure 1 Conceptual framework of the study

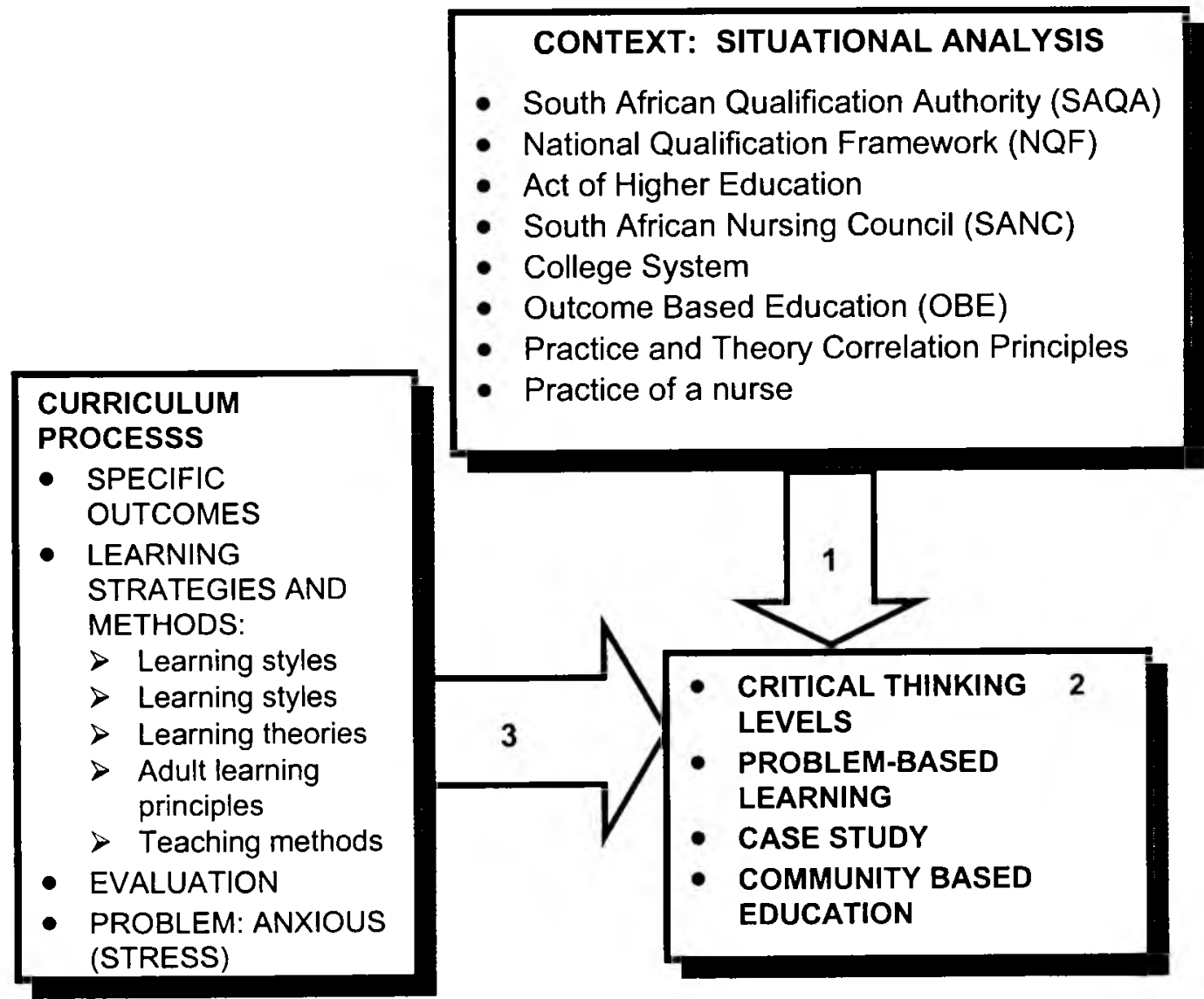

\section{Context: Situational analysis}

In this study the context of problem-based case study was based on the views of SAQA (SAQA, 1997); NQF, Act of Higher Education, SANC (1992), College system, Outcomes-based Education, Practice and Theory Correlation Principles and Practice of Nursing.

The Commission on Higher Education made recommenda- 
tions that health institutions revise their curricula in order to equip health care students and health care personnel educators with knowledge, competency, attitudes, and comprehensively to respond to the health care needs of the population of South Africa. The South African Qualification Authority (SAQA, 1997) critical outcomes, namely problem solving skills, team ship, self-responsibility skills, research skills, communications skills, technological and environmental, and literacy and developing micro-vision can be applied in problem based case study. SANC (1992:3) explicitly indicates in its philosophy that the development of critical analytical thinking in the nursing student is essential. The context situational analysis clearly depicts that nursing practice needs an independent practitioner who is a critical thinker and good problem solver. A possible solution is the implementation of problem-based case study as a teaching strategy. Therefore, we need to describe concepts related to problem-based case study.

\section{Definition of key concepts}

\section{- $\quad$ Critical thinking}

In this study critical thinking means rational analysis and evaluation of ideas, influences, assumptions, principles, arguments, conclusions, issues, statements, beliefs, and actions (Bandman \& Bandman 1995:7; Paul, 1990; Paul \& Heaslipp, 1995:40).

\section{- $\quad$ Problem-based case study}

Reilly and Oermann (1992:239) state that the case study provides a holistic view of client's problems and promote problem solving learning. Problem-based learning is defined as an instructional method characterised by the use of patient problems as a context for students to learn problem-solving skills and acquire knowledge about the basic and clinical sciences (Albanese \& Mitchell, 1993:53). Barrows (1997) (nㅡ Adejumo 1997:1) in an attempt to explicate the meaning of problem-based learning, presented the following key words to describe problem-based education namely, student centred, integrative problem-based, inquiry based, self-directed, collaborative, re-interactive, self-monitored, and practice based.

\section{- Community based education}

Community based education is a means of achieving educational relevance to community needs. Key principles of community-based education are namely, community centred learning multi disciplinary learning, intersectoral collaboration, and community based learning activities (Adejumo, 1997:4).

\section{- Curriculum Process}

The curriculum process was used as a framework for the program of the problem-based case study. The curriculum process includes the following aspects:

\section{- $\quad$ Specific outcomes}

In this study specific outcomes were related to basic health needs of patients. The learners should demonstrate knowledge, skills and attitudes for the assessment, diagnoses, planning, implementation and evaluation of the elimination health needs and problems of the individual patient.

\section{- $\quad$ Learning theories and principles}

Learning theories view learning from different philosophical perspectives. In this study emphasis was based on theories from which the constructivistic theory developed namely:

- Meaningful verbal learning theory of Ausubel (1963:35).

- Bruner's discovery learning theory, which emphasised student's active involvement (Mellish et al, 1998:31).

- Vygotskys theory of interactional learning which em phasised the roles of cultural and social process, as well as language, in mediating cognitive development (Mellish et al, 1998:32).

Nursing students are regarded as adult learners because of clinical milieu demands. The following assumptions regarding adult learning are relevant (Knowles, 1971) (in Mellish et al, 1998:67-68):

- $\quad$ adult learners need to know why they must learn some thing

- a learner moves from dependence to independence during maturation

- $\quad$ experience plays a role in learning

- adults readiness to learn relates to the things that adults need to know and do in real life

- adult learners have a life-control orientation to learn ing and adult learners' motivation is largely internal.

\section{Relevant teaching methods}

The matching of adult learning principles and cognitive learning styles with teaching methods is widely held to result in greater learning achievement, greater learner satisfaction and use of learning experience, improved understanding and better learning comprehension. The following are relevant teaching methods that should encourage an adult learner to be actively involved in learning and use her previous experiences in solving the problem, namely case study, problem-based case study, group discussion, mentoring, preceptor ship and accompaniment.

\section{Evaluation}

Evaluation in this study relates to outcomes-based education. Assessment criteria were formulated for the evaluation or assessment of learning outcomes.

\section{FINDINGS}

\section{Principles for a problem-based case study program (phase 1)}

From the conceptual framework the following principles were identified and used for the development and implementation of the program for problem-based case study:

- $\quad$ Principles of community-based education and adult learning as described under conceptual framework.

- The learner should demonstrate knowledge, skills and attitudes related to the assessment, diagnoses, planning, implementation and evaluation of the health needs and problems (principles of outcome-based education and the nursing process). 
- $\quad$ The case must be presented as a problem.

- $\quad$ Assessment criteria (knowledge, skills, values and attitudes) to be used in evaluation/assessment of student learning. Specific learning outcomes and as sessment criteria should be formulated for each aspect of the learning content.

- $\quad$ Pre-knowledge, related to basic sciences should be assessed.

- $\quad$ The learning that has occurred in working with the problem and self-directed study is integrated into the students' framework of existing knowledge, skills and attitudes.

- $\quad$ Assess student by self-evaluation, peer evaluation and tests.

- $\quad$ Feedback by tutor.

With the implementation of the problem-based case study program/approach students were divided into groups of four or five in different clinical units. The following protocol was used with the implementation of the program.

- A group of students in each clinical unit were as signed to identify a patient with elimination need/ problems.

- After identifying a patient, they were then expected to identify and study relevant theoretical frameworks from basic sciences. During the presentation of the patient, students were asked to justify the assessment data, diagnoses, planning and implementation based on the theoretical framework of the basic sciences, like physiology.

- During presentation, students were expected to use the nursing process as a guideline to solve the identified problem.

- After presentation followed self-evaluation, peer evaluation and feedback from the tutor.

\section{Phase II: Experiences of student nurses}

The objective of phase two was to explore and describe experiences of student nurses who were exposed to problem-based case study. The experiences were divided in positive and negative.

Table 1: Provides a schematic representation of six main categories and sub categories of student experiences, which were generated from the coding of naive stretches.

\section{Phase III: Perceptions of tutors}

The objective of phase III is to explore and describe the perceptions of tutors regarding the implementation of the problem-based case study in clinical setting. A focus group was conducted with ten tutors. Table 2 shows an overview of categories of focus group results.

\section{Table 1 Categories of student experiences}

\section{Positive experiences \\ Holistic approach}

- $\quad$ Holistic understanding of patients needs and problems

- Improve interaction with patient

- Understand and are able to give health education to patient

Gained a lot. It helps to understand the patient problem/ need

Meaningful learning

Comprehensive learning

Focus on problems and understanding nursingcare for a patient with a specific need/problem better.

\section{Skill development}

- $\quad$ Thinking skills are developed

- Skill on history taking, assessment, formulation of nursing diagnosis and planning, intervention were developed

- Development of problem solving skills without the help of a doctor.

\section{Student involvement}

- Interesting

- Student centred

- Active participation

- Self, peer and tutor assessment

- $\quad$ Build self - confidence

- $\quad$ Encourage group work

- $\quad$ Address adult learning principles

\section{Correlation of theory and practice}

- Good correlation between theory \& practice

- Understanding the logic of relevant of theory

- Remember better

\section{Negative experience}

- $\quad$ Poor performance

- $\quad$ Anatomy and physiology not well presented by other groups

Anxiety

Lack of group leaders

Inadequate time for skill feedback

Interference with feedback for basic skills 


\section{Table 2. Categories of focus group results}

\section{Curriculum Review}

- A need to review curriculum, it must be problem based curriculum.

- $\quad$ Redesign clinical workbook in such a way that it en courages student participation

it must contain problems on human needs

student nurses must assess patients with basic needs and solve these problems.

\section{Training Schedule}

- Redesign present schedules especially time tables. The theory to be presented in the morning and correlation of the theory and practice in the afternoon.

\section{Multi - disciplinary learning}

- Involvement of registered nursed, in the clinical units to act as preceptors in the units for the student.

- Multi-disciplinary team members must be involved, for example doctors, social workers and psychologist and physiotherapist.

- $\quad$ All disciplines must work together

- Mini research problem in various disciplines.

\section{Library facilities}

- Library time for students to be increased

- Improvement of library facilities provision of enough seating facilities

- accessibility at all times especially in the evening.

\section{Implementation of problem- base case study}

- Implementation of the problem-based case study at all levels.

- $\quad$ Expose the student first in the situation before expo sure to theory so that they can utilise their own previ ous knowledge.

- $\quad$ Student and teacher empowerment.

\section{Conclusions: Guidelines and operationalisation of problem-based case study}

Data derived from Phase I. II, III were used to formulate guidelines for operationalisation of problem-based case study (phase IV).

\section{Guideline 1}

Problem-based case study should emphasise the importance and enhance skills, knowledge, and values of nursing care.

\section{Operationalisation}

To operationalise this guideline the following action should be implemented using the example of elimination needs. The method, strategies and resources used must be compatible with adult education principles in a tertiary educational setting.

- $\quad$ Activate pre-knowledge of all basic science for better understanding of the problem. Students need to know the anatomy and physiology, social science and natural science related to each problem. Self-evaluation pre-test can be employed to activate the pre-knowledge.

- Provision of adequate time to practice basic skills before formative evaluation, for example, he/she will be expected to practice the following skills namely giving of a bedpan, administration of suppository and giving an enema. This is followed by a competency test of skills by the tutor during formative and summative evaluation.

- Use of critical thinking, problem solving and group skills should be encouraged through the assignment of problem-based case study.

- Inculcate value of respect, empathy, responsibility, autonomy and dignity of the client or patient. For example, providing privacy can ensure the dignity of a client/ patient. Emphasis should be placed on multicultural aspects of the community. Respect for $t$ he human rights of client/ patient.

- Use nursing process that includes assessment, diag noses, planning, implementing and evaluation of basic human needs.

- Utilising adult learning principles, which are active learning, deep-holistic life long learning and constructivistic learning.

- Use of outcomes-based approach as stipulated by the South African Qualification Authority requirements.

- Use of a competency based approach with competence in theoretical and practical aspects.

- Use of a problem-based learning approach, which is a method preferred by adult students.

- $\quad$ Provision of clinical accompaniment by the tutor to enhance theoretical and practical correlation.

- Provision of mentoring of students by the nurse educator to empower and enable students.

Provision of preceptor ship of students in a clinical setting.

Use of inductive strategy, where the students have to discover information by themselves.

Use of deductive strategy, when a general principle is used in specific cases

Use of co-operative strategy, where group work is essential for learning, for example, group discussion. Use of facilitation, where the tutor makes it easier for students to participate in otherwise difficult events.

\section{Guideline 2}

Review of curriculum to accommodate problem-based case study, outcomes-based education and training and commu- 


\section{Operationalisation}

To operationalise this guideline, the South African Qualification Authority expects the whole curriculum to have the following critical outcomes.

- Learners will identify and solve problems and make decisions using critical and creative thinking. For example, students are expected to identify causes of faecal elimination problems such as constipation, and solve this accurately using critical and creative thinking skill.

- Learners will work effectively with others in a team, group, organisation or community. For example, in this study students are allocated in groups of four or five in various clinical units. They are expected to discuss patient problems in a group. This helps them to share ideas and learn to establish good interpersonal relationships with other team members.

- $\quad$ Learners will organise and manage themselves and their activities responsibly and effectively. For example, although we expect them to work in a group, we also expect them to work as individuals. Students are expected to share the work among them in preparation for presentation to peer members, presenting anatomy and physiology or conducting an interview.

- $\quad$ Learners will collect, analyse, organise and critically evaluate information. For example, students are expected to conduct an assessment of a patient with an elimination problem. He/she must critically organise and analyse the information in order to come up with an accurate nursing diagnosis and an intervention of a patient's needs/problems.

- $\quad$ Learners will communicate effectively using visual, symbolic and or language skills in various modes. For example, students learn to communicate effectively with a patient with a faecal elimination problem, communicate effectively with other members of the team during group discussion, have the opportunity to present the case study and even write theoretical parts related to faecal elimination.

- $\quad$ Learners will use science and technology effectively and critically showing responsibility. Problem-based case study helps students to apply, for example, physical science in solving faecal elimination by encouraging the patient to maintain thigh flexion, which in creases the pressure in the abdomen.

- Learners will demonstrate an understanding of the world as a set of related systems by recognising that the problem-solving context does not exist in isolation. Students are made to think divergently that, for example, constipation can have various causes, such as psychological problems, namely, lack of privacy, lack of activity in orthopaedic or critically ill patients and abuse of laxatives.

- $\quad$ Reflecting on and exploring a variety of strategies to learn more effectively. For example, outcomes based education expects the learner to be a self-directed learner seeking information related to faecal elimination from a textbook on his/her own and discussion of faecal problems with other team members. It en- occurs in the real world.

- Participating as responsible citizens in the life of local, national and global communities. For example, during discussions of an elimination problem, students develop a team spirit. Such qualities can even be transferred to organisations and communities from where the student comes.

- $\quad$ Being culturally and aesthetically sensitive across a range of social contexts. For example, students should respect cultural beliefs of the patient, and those of peers, especially during group discussions.

- Exploring education and career opportunities.

- Developing entrepreneurial opportunities.

- $\quad$ Redesigning of the curriculum to a problem-based ap proach, for example, revisiting philosophy, vision and mission, teaching methods, and evaluation methods.

- $\quad$ Redesigning of the clinical workbook in such a way that it enhances student participation. The workbook must have problems on human needs and students must assess patients with basic needs and solve the problem.

- Modification of the training schedule, so that the afternoons should be reserved for the correlation of theory and practice.

- The focus will be more community-based rather than institutional.

- Forming learning outcomes in knowledge, skills, attitudes and values in General Nursing Science.

\section{Guideline 3}

Utilisation of multidisciplinary learning by using other members of the health team.

\section{Operationalisation}

To operationalise this guideline, the following should be implemented:

- Other multidisciplinary members must be involved, such as doctors and physiotherapists, in the teaching of students.

- Members from various disciplines, for example the Community Nursing Science, Midwifery Science, General Nursing Science and Psychiatric Nursing Science work as a team. Reformulation of problems is institutional or community-based.

- Workout competencies should be at the end of the education program rather focusing on a specific discipline

\section{Guideline 4}

Library facilities need to be improved, to meet the needs of the students.

\section{Operationalisation}

To operationalise this guideline the following actions should be implemented: 
- $\quad$ Adequate library facilities, such as books, journals, videos, and computers, sufficient seating facilities e.g. desks and chairs

- $\quad$ Accessibility at all times especially in the evening until $21 \mathrm{~h} 00$.

\section{Guideline 5}

Accurate student allocation and training schedules should be done in such a way that it enhances their knowledge, skills, attitudes and values in nursing care. Student learning needs should be considered.

\section{Operationalisation}

To operationalise this guideline, the following actions should be implemented:

- Effective clinical allocation during the learning program should be in a general hospital unit as well as in the community so that the student gains more exposure to nurse patients with various basic human needs.

- Effective integration of theory and practice

- $\quad$ Provision of adequate time for students to practice the skill required for preparation of formative and summative evaluation

- Allocation of students into groups, when preparing problem-based case study.

\section{Guideline 6}

Assessment (evaluation) in problem-based case study is compulsory to evaluate whether the outcomes in knowledge, skills, attitude and values have been achieved.

\section{Operationalisation}

To operationalise this guideline, the following actions should be implemented:

- $\quad$ Assessment will be done on specific outcomes and according to assessment criteria.

- Assessment will be in the form of diagnostic assessment, formative assessment and summative assessment.

- The above assessment will be achieved by conduct ing pre-testing, standardised testing, assignments, clinical performances, student feedback, case study research and essay projects.

\section{Guideline 7}

Redesigning of the clinical workbook in such a way that it encourages active student participation.

\section{Operationalisation}

To operationalise this guideline, the following should be implemented:

- The workbook must be used throughout their clinical placement to enhance learning

- The workbook should have due dates for completion to ensure that it is presented for formal evaluation

The workbook should consist of psychomotor skills and problem-solving skills related to basic human needs.

\section{Guideline 8}

The effective integration/correlation of theory and practice to enhance knowledge, skills, attitudes and values.

\section{Operationalisation}

To operationalise this guideline the following should be implemented:

- A competency-based approach will be used to en sure competence in theory and practice. These competencies include knowledge skills, problem solving, critical thinking, ethical decision making, listening, interviewing, assessing community needs and self directed study.

- Clinical accompaniment by the tutor to enhance theoretical and practical correlation.

- Mentoring of students by the nurse educator to empower and enable students.

- Preceptor supervision of students in the clinical areas is required.

- $\quad$ Facilitation where the tutor makes it easier for students to participate in otherwise difficult events.

- Planning of a program.

\section{Guideline 9}

Problem-based case study should focus on the development of critical thinking skills.

\section{Operationalisation}

To operationalise this guideline, the following should be implemented:

- $\quad$ Activation of prior knowledge plays an important role in learning. Teaching requires not only the imparting of new information but also the conveying of meta-knowl edge in such a way that it will restructure old ways of knowing.

- $\quad$ Self-directed learning. This can be enhanced by the use of modules, learning contracts and the use of self directed computer laboratories.

- The use of clinical journals to enhance critical thinking.

- $\quad$ Engage students in reasoning. During reasoning, people should treat one another as equals.

- The attitude of the teachers and the intellectual atmosphere of the class have to instil confidence in students that rational disagreement will not be penalised in any way but highly rewarded.

- Utilisation of teaching strategies that will stimulate higher order thinking such as Critical thinking, analysis, synthesis, application, writing and problem solving.

- $\quad$ Begin activities with structured group experiences and proceed to the analysis, evaluation and application of what was learned.

- Critical thinking must be taught as an integral part of other nursing program subjects. 


\section{Discussion of the findings and conclusions and recommendations}

The students' experiences with the problem-based case study approach/program were mostly positive. The program facilitated a more holistic approach and better understanding of the patients and their health problems/needs. The program also contributed to the development of independent problem solving and thinking skills for the assessment, diagnosis, planning, implementation and evaluation of nursing care. The students became active participants in the learning process and learned to work together as a team. The problem-based case study approach also facilitated better theory-practice correlation. The students related the negative experiences to the anxiety experienced by the students and the inadequate feedback and discussion of the basic sciences.

The tutors were very enthusiastic about the problem-based case study approach. They recommended a change in the curricula, clinical workbooks and the education time schedule to accommodate the new approach. They also emphasised a multidisciplinary involvement in the new approach and the improvement of supportive facilities like the library.

From the students and tutors experiences and perceptions, the problem-based case study approach seemed to be a viable clinical teaching strategy for the nursing college. For the operationalisation, of the problem-based case study approach in clinical nursing education, the aspects of the students' experiences and tutors' perceptions were integrated in the nine guidelines.

The following recommendations for further research were made, namely: To test/measure whether the problem-based case study approach will enhance the development of critical thinking. In order to measure the development of critical thinking in student nurses, a cultural sensitive instrument should be developed in Nursing Education in South Africa.

\section{References}

ADEJUMO O 1997: Key principles of problem-based learning and community based education. (A paper presented at National Nursing Education Workshop 26-27 August 1997).

ALBANESE, MA \& MITCHELLS 1993: Problem-based learning: a learning: a review of literature on its outcomes and implementation issues. Academic Medicine, 68 (1) 1993: 52-81.

ARUNACHALLAM, S 1999: Community based curriculum in psychiatric nursing science. M Cur. Johannesburg: Johannesburg : Rand Afrikaans University.

AUSUBEL, D P 1963 : The Psychology of meaningful verbal learning. New York: Grune \& Stratton

BANDMAN, E \& BANDMAN,B 1995: Critical thinking nursing, $2^{\text {nd }}$ Edition. Norwalk G.T. + Appleton on large.
Boston. Allyna Bacon. Handbook of college teaching, theory and applications. London: Greenwood Press: 3-22.

BURNS, N \& GROVE, SK 1993: The practice of nursing research: conduct, critique and utilization, $2^{\text {nd }}$ Edition. London: W.B. Saunders Company.

BROWN, N H \& SORREL, J M: The use of clinical journal to enhance central thinking. Nurse Educators. 18, (5) September / October 1993: 16- 18.

CRESSWELL, J W 1994: Research design: Qualitative and quantitative approval. London: Sage Publications.

DEMOCRATICNURSING ORGANISATIONOFSOUTHAFRICA 1998: Ethical Standards for nurse researchers. Pretoria : DENOSA.

KLAASENS, E L 1988: Improving teaching for thinking. Nurse Educator. 13(7): November/ December 1988: 15-19.

KRUEGER, RA 1994: Focus Groups, Second edition. London: Sage.

ILSON, CRYSTAL, D, WELL,J C,LONG,T L \& CARNEY, F 1987: Readers digest Universal dictionary. London: Readers Digest Association Limited.

KLOPPER, H C 1998 : Nursing education : a reflection. Johannesburg : Siyferelf Publishers.

LINCOLN, NS \& GUBA, E G 1985: Naturalistic inquiry. London: Sage Publishers.

MELLISH, J M, BRINK, H \& PATON, F 1988: Teaching and learning the practice of nursing, $4^{\text {th }}$ Edition. Heinemann: Johannesburg.

MORTON, M \& “SALJO”, R 1976: On qualitative differences in Learning process and outcome. British Journal of Educational Psvchology. 46 1976: 4-11.

PASH, G 1976: Styles and strategies of learning. British Journal of Psvchologv. 76: 128-148.

PAUL, RW 1990: Critical thinking. Rohnert Park: Sonoma State University.

PAUL, RW \& HEASLIPP 1995: Critical thinking and intuitive nursing practice. Journal for Advanced Nursing. 22 1995: 40-47.

POLIT, D F \& HUNGLER, B P 1997: Essentials of Nursing research - methods, appraisals and utilisation. United States of America: J.B. Lippincot company.

REILLY, D E \& OERMANN, M H 1992: Clinical teaching in nursing education, $2^{\text {nd }}$ Edition. National League of Nursing: New York.

SOUTH AFRICAN NURSING COUNCIL 1992: The philosophy and policy of the South African Nursing Council with regard to professional education and training. SANC : Pretoria.

SOUTHAFRICANQUALIFICATIONSAUTHORITY 1997: 2 (2): November/December 1997. 